\title{
Mucilage Wastes as a Source for Oils: Part I: Preparation of Anionic Surfactants
}

\author{
M.G. Megahed", M.A. Abd El-Ghaffar*, A. Shahin ${ }^{* *}$ and \\ A.M. Rabie ${ }^{* * *}$ \\ Department of Fats and Oils, *Department of Polymers and \\ Pigments, National Research Centre, Cairo, Egypt, ${ }^{* *}$ Corgal, \\ Algeria and ${ }^{* * *}$ Department of Chemistry, Faculty of Science, \\ Ain-Shams University, Cairo, Egypt.
}

\begin{abstract}
UCILAGE wastes are industrial by-products which are rich in oils. The extracted oils were characterized via spectrophotometric measurements (e.g. IR, ${ }^{1} \mathrm{HNMR}$ ) and utilized in the preparation of some surface active agents. Two anionic surfactants were prepared via sulfatation by concentrated sulfuric acid and sulfonation by dry sulfur trioxide from sunflower and cotton seed oils. Yields of the prepared surfactants were $70 \%$ and $71 \%$, respectively.

The microanalysis data of $(\mathrm{C}, \mathrm{H}, \mathrm{S})$ were estimated. In addition, the hydrophilic - lipophilic balance (HLB), surface tension, interfacial tension, wetting and foaming power and biodegradability for the prepared surfactants were evaluated.

The importance of these anionic surfactants are due to their environmental friendly nature and relatively safe application to human in addition to their economical feasibility.

Biodegradation is also an important parameter which was taken into consideration. The prepared surfactants showed more than $95 \%$ degradation after 21 days that can be considered a great success for environment.
\end{abstract}

Keywords: Mucilage wastes, Sunflower oil, Cotton seed oil, Anionic surfactants, Sulfatation, Sulfonation and Biodegradation.

Natural oils are widely used in the pharmaceutical, cosmetics and detergent industries for their environment friendly nature and relatively safe applications to human $^{(1,2)}$. The purpose of this study is to develop a new surface - active agent compound in different forms to serve the home and personal care applications. In addition, the study undertakes the exploitation of making the utmost use of residual waste or obsolete by-products resulting from food industries ${ }^{(3)}$.

\footnotetext{
\#Corresponding author, E-mail: dr_mgmegahed @ hotmail.com
} 
One of these industrial was materials is mucilage, which is a by-product resulting from refining processes of edible oils, which produced from oil seeds , such as sunflower and cotton seed oils ${ }^{(4)}$.

Mucilage production in Egypt is estimated as more than one million ton per year. It contains about $20 \%$ crude oil that was successfully almost extracted in full, which if converted into surfactants will deliver more than $30 \%$ gross profit value when sold at market .

These cheap kinds of by-products, such as mucilage are selected for preparation of anionic surfactants by sulfatation and sulfonation processes. The prepared surfactants were compared with some commercial standard anionic surfactants on the basis of hydrophilic-lipophilic balance (HLB), surface and interfacial tension, as well as, wetting and foaming power ${ }^{(5)}$.

\section{Materials}

\section{Materials and Methods}

Mucilage samples of sunflower and cotton seed oils were supplied by Misr Oil \& Soap Company, Sandob and Salt \& Soda Company for Oils and Soap, ElZayat ( Egypt ). Anionic surfactants were prepared from high purity chemicals. They were obtained individually from various international companies, e.g. BDH ( England ), Henkel ( Germany ) and Fisher (USA) .

\section{Methods}

Fatty acid composition of extracted oil

Fatty acid methyl esters were prepared according to A.O.C.S method ${ }^{(6)}$. Determination of fatty acid composition was performed as previously described $^{(7)}$ using Hewlett Packard 5890 Series II gas chromatography, equipped with flame ionization detector ( FID ).

Preparation of anionic surfactants by:

Sulfatation process: The sulfatation of the extracted oils was carried out according to the ${ }^{(8)}$ taking into consideration various reaction parameters, e.g . temperature, time of reaction and concentration of sulfuric acid in order to determine the optimum conditions for large scale production. The extracted oil was poured into a three-necked flask, and subjected to heating at $45^{\circ} \mathrm{C}$, after that sulfuric acid $90 \%$ concentration was dropped with stirring and keeping temperature around $45-50^{\circ} \mathrm{C}$. The sulfated oils were washed many times using $10 \%$ sodium chloride solution at ambient temperature. After a pause of 1-2 hr of washing the sulfated oils were floating on the surface and separated from decanted acid brine. Then the mass floating on the surface is neutralized with concentrated caustic soda ( $48 \%)$.

Sulfonation process: The extracted oils were sulfonated by dry sulfur trioxide ${ }^{(9)}$. This process has many advantages than sulfatation such as lightness of color in the final product, low sulfuric acid content, and better yield .

Egypt. J. Chem. 53, No. 4 (2010) 
Infrared spectroscopic analysis: The infrared spectra were performed using Perkin Elmer Model 550SE spectrophotometer, USA .

Nuclear magnetic resonance sepectroscopic analysis: The ${ }^{1}$ NMR spectra were run on a Jeol Ex $270 \mathrm{NMR}$ spectrometer, $270 \mathrm{MHz}$ (USA) with super conducting magnet Oxford and $5 \mathrm{~mm}$ Dual probe head for ${ }^{1} \mathrm{H}$.

Evaluation of anionic surfactants

Microanalysis: The microanalysis of carbon $(\mathrm{C})$, hydrogen $(\mathrm{H})$ and sulfur (S) were carried out using a Perkin Elmer 240B Microanalyzer (USA) .

Hydrophilic - lipophilic balance ( HLB ): Hydrophilic - lipophilic balance of anionic surfactants were determined ${ }^{(10)}$ using the following equation :

$$
\mathrm{HLB}=20(1-\mathrm{S} / \mathrm{A})
$$

where: S (Saponification value of sulfated and sulfonated oils) and A (acid value of total fatty acids of the original sample after hydrolysis of triglyceride fraction)

Surface and interfacial tension: Surface and interfacial tension of anionic surfactants in xylene at $25^{\circ} \mathrm{C}$ was measured ${ }^{(11)}$ using CSC - DuNouy Interfacial Tensiometer Model 70545 (CSC Scientific Company, Fair fax, Va) .

Wetting power: Wetting power of prepared surfactants was determined according to the method of Schigfner ${ }^{(12)}$ based on immersing a skein of standard textile sample with fixed concentration, temperature, hardness of water and period of aging.

Foaming power: Foaming power of prepared surfactants was determined according to the method of Ross and Miles ${ }^{(13)}$. Various parameters must be established during the test, such as concentration of surfactant, water hardness, temperature of solution and period of aging.

Biodegradability of an ionic surfactant: Two biological test methods (OECD screening test and OECD confirmatory test) are mandated for establishing biodegradability according to organization for economic cooperation and development $(\mathrm{OECD})^{(14)}$.

a) OECD screening test

The OECD screening test is preliminary test for exploring the biodegradability of detergents. In this producer, a mineral salt solution is incubated of MBAS (Methylene blue active substance) or BiAS (Bismuth active substance) as the role source of carbon. The MBAS or BiAS loss is determined at fixed intervals for up to 19 days, and the results are compared to the behavior of two control substances:

The poorly degradable TPS (tetra propylene benzene sulfonate) ( $<35 \%$ loss) and the readily degradable LAS (linear alkyl benzene sulfonate) (92\% loss). 
b) OECD confirmatory test

The OECD confirmatory test is a continuous procedure more closely related to practice. It simulates through a prescribed test procedure the biodegradation that occurs in an activated sludge. These methods are reported by Vorodnung and Reinigung smitteln ${ }^{(15)}$.

\section{Results and Discussion}

Physical and chemical characteristics of extracted oils have been extensively investigated and carried out according to standard methods of American Oils Chemists Society A.O.C.S (6). The data of color, density, refractive index (R.I), iodine value, acid value, saponification value, unsaponifiable matter and peroxide value are given in Table 1.

TABLE 1. Physical and chemical characteristics of extracted oils.

\begin{tabular}{|l|c|c|}
\hline Characteristics & Sunflower oil & Cotton seed oil \\
\hline & Liquid-Clear-Yellow & Liquid-Clear-Yellow \\
Appearance & 0.20 & 2.50 \\
Klett color & 0.919 & 0.930 \\
Density (g/cm3 ) & 60.0 & 72.0 \\
Viscosity (cm boize) & 1.476 & 1.474 \\
Refractive index & 129.0 & 110.0 \\
Iodine value & 185.0 & 190.0 \\
Saponification value & 2.0 & 2.6 \\
Acid value & 2.0 & 1.7 \\
Unsaponifiable matter & 1.1 & 0.9 \\
Peroxide value & & \\
& & \\
\hline
\end{tabular}

From Table 1 it can be concluded that :

a) The most physical properties are within the standard.

b) Iodine value which represents the degree of unsaturated fatty acids indicates that sunflower oil has higher values [129] compared with cotton seed oil [110].

c) Acid value measurements show that sunflower and cotton seed oils have approximately moderate values of free fatty acid.

d) Saponification value, unsaponifiable matter and peroxide value: these values indicate that these results are almost the same for both extracted sunflower and cotton seed oils from mucilage.

Fatty acids composition of extracted oils are recorded in Table 2. 
TABLE 2. Fatty acids composition of extracted sunflower and cotton seed oils from mucilage.

\begin{tabular}{|c|c|c|c|c|c|c|c|c|c|c|c|c|c|c|}
\hline $\begin{array}{c}\text { Mucilage } \\
\text { oils }\end{array}$ & \multicolumn{10}{|c|}{ Fatty acids \% } \\
\cline { 2 - 12 } & \multicolumn{10}{|c|}{ Saturated fatty acids } & \multicolumn{7}{c|}{ Unsaturated fatty acids } \\
\cline { 2 - 12 } & $\mathbf{C}_{12}$ & $\mathbf{C}_{14}$ & $\mathbf{C}_{16}$ & $\mathbf{C}_{18}$ & $\mathbf{C}_{20}$ & $\mathbf{C}_{22}$ & $\mathbf{C}_{24}$ & $\mathbf{C}_{14: 1}$ & $\mathbf{C}_{16: 1}$ & $\begin{array}{c}\mathbf{C}_{18: 1} \\
(\mathbf{O H})\end{array}$ & $\mathbf{C}_{18: 1}$ & $\mathbf{C}_{18: 2}$ & $\mathbf{C}_{18: 3}$ & $\mathbf{C}_{20: 1}$ \\
\hline Sunflower & 0.00 & 0.50 & 6.50 & 8.75 & 4.00 & 1.00 & 0.40 & 0.00 & 1.00 & 0.00 & 30.00 & 45.80 & 0.70 & 0.50 \\
Cotton & 0.00 & 1.00 & 22.5 & 2.00 & 0.90 & 0.20 & 0.00 & 0.10 & 1.35 & 0.00 & 23.05 & 48.35 & 0.55 & 0.00 \\
\hline
\end{tabular}

C12, Lauric ; C14, Myristic ; C16, Palmitic ; C18, Stearic ; C20, Archidic ; C22, Behenic ; C24, Lignoceric ; C14:1 , Myristoleic ; C16:1, Palmitoleic ; C18:1(OH), Ricinolic ; C18:1, Oleic ; C18:2, Linoleic ; C18:3, Linolenic ; C20:1, Gadoleic .

It can be seen from Table 2 that the fatty acid contents of sunflower and cotton seed oils were $(21.15 \%$ and $26.6 \%)$ of saturated fatty acids , and $(78.0 \%$ and $73.40 \%$ ) of unsaturated fatty acids, where the saturated : unsaturated ratio were (1:3.7) and (1:2.7), respectively .

Oleic acid constitutes more than $38.0 \%$ and $31.0 \%$ of the unsaturated fatty acids of sunflower and cotton seed oils, while stearic acid makes more than $16.0 \%$ and $7.0 \%$ of the saturated fatty acids, respectively. On the other hand, linoleic acid forms more than $45.0 \%$ and $48.0 \%$ of the total fatty acids of sunflower and cotton seed oils, respectively ${ }^{(16-19)}$.

Structure of the extracted triglycerides was established through ${ }^{1} \mathrm{H}-\mathrm{NMR}$ $\left(\mathrm{CDCl}_{3}\right)$ which shows the following results: $\delta 0.9\left(\mathrm{t}, \mathrm{CH}_{3}\right), \delta 1.5$ (br., $\left.\mathrm{CH}_{2}\right), 2$ (br., $\left.\mathrm{CH}_{2}\right), \delta 2.3(\mathrm{t}, \mathrm{CH}-\mathrm{OH})$ and shows also the unsaturated protons as triplet single at $\delta 5.4$.

The IR spectrum of extracted oils showed strong absorption bonds at 3020 $\mathrm{cm}^{-1}$ which correspond to olefinic group $(=\mathrm{CH})$ and at 1680 to $1710 \mathrm{~cm}^{-1}$ which correspond to glyceridyl ester group.

\section{Preparation of anionic surfactants by sulfatation process}

Preparation of anionic surfactants via reaction with sulfuric acid. The advantage of this technique is the formation of a good yield product characterized by lower free oil and deeper color compared with that obtained by the sulfatation process ${ }^{(20)}$. In this method two types of sulfonating products are obtained via attacking the ester group or the unsaturated double bond of fatty acids $^{(21)}$. Adding sulfuric acid as a sulfating agent to the extracted oils, sulfatation can be carried out on either hydroxyl group $(-\mathrm{OH})$ or double bond $(-\mathrm{CH}=\mathrm{CH}-)$ of olefinic chain ${ }^{(5,22)}$. 
The reaction can be illustrated in the following scheme :

$$
\mathrm{FA}-\mathrm{OH}+\mathrm{H}_{2} \mathrm{SO}_{4} \rightarrow \mathrm{FA}-\mathrm{O}^{-}-\mathrm{SO}_{3}{ }^{-} \mathrm{H}^{+}+\mathrm{H}_{2} \mathrm{O}
$$

By neutralization with sodium hydroxide the sulfate (salt) was obtained and the product is considered as fatty acid ester sulfate due to presence of the ester bond .

$$
\mathrm{FA}^{-} \mathrm{OSO}_{3}{ }^{-} \mathrm{H}^{+}+\mathrm{NaOH} \rightarrow \mathrm{FA}^{-} \mathrm{O}^{-} \mathrm{SO}_{3}{ }^{-} \mathrm{Na}^{+}+\mathrm{H}_{2} \mathrm{O}
$$

This salt can be considered as extremely hydrophilic surfactant and less hydrophilicity can be attained with a longer chain .

$$
\mathrm{FA}^{-} \mathrm{CH}=\mathrm{CH}^{-} \mathrm{COOR}+\mathrm{H}_{2} \mathrm{SO}_{4} \rightarrow \underset{\mathrm{O}^{-} \mathrm{SO}_{3}{ }^{-} \mathrm{H}^{+}}{\mathrm{FA}^{-} \mathrm{CH}^{-} \mathrm{CH}_{2}-\mathrm{COOR}}
$$

and also by neutralization with sodium hydroxide the sulfate (salt) was obtained .

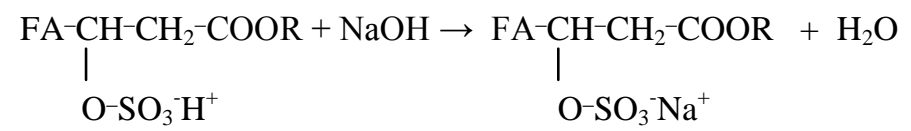

Results of optimum conditions as well as yield and microanalysis of prepared

\begin{tabular}{|c|c|c|c|c|c|c|c|c|c|c|}
\hline \multirow{3}{*}{ Sulfated oil } & \multicolumn{3}{|c|}{ Optimum conditions } & \multirow{3}{*}{$\begin{array}{c}\text { Yield } \\
(\%)\end{array}$} & \multicolumn{6}{|c|}{ Microanalysis } \\
\hline & \multirow{2}{*}{$\begin{array}{c}\mathrm{H}_{2} \mathrm{SO}_{4} \\
(\mathrm{~m} 1)\end{array}$} & \multirow{2}{*}{$\begin{array}{l}\text { Reaction } \\
\text { Temp. } C^{\circ}\end{array}$} & \multirow{2}{*}{$\begin{array}{l}\text { Reaction } \\
\text { Time hr }\end{array}$} & & \multicolumn{2}{|c|}{ C \% } & \multicolumn{2}{|c|}{ Н \% } & \multicolumn{2}{|c|}{$\mathrm{S} \%$} \\
\hline & & & & & Theo.* & Fd.** & Theo. & Fd. & Theo. & Fd. \\
\hline Sunflower & 50 & 34 & 2.5 & 61.0 & undefined & 27.83 & undefined & 4.78 & 8.30 & 8.23 \\
\hline Cotton seed & 40 & 34 & 2.0 & 71.0 & "" & 27.24 & "" & 4.68 & 8.38 & 8.27 \\
\hline
\end{tabular}
anionic surfactants are presented in Table 3.

TABLE 3. Optimum conditions, yield and microanalysis of anionic surfactants.

Theo. $=$ Theoretical $\quad{ }^{* *}$ Fd. $=$ Found

It can be seen from Table 3 that the optimum reaction temperature of both sulfated sunflower and cotton seed oils are the same $\left(34 \mathrm{C}^{\circ}\right)$, while the obtained data revealed that the optimum reaction time of both sulfated sunflower and cotton seed oils were $(2.5 \mathrm{hr})$ and $(2.0 \mathrm{hr})$, respectively. On the other hand the microanalyses data for $(\mathrm{C}, \mathrm{H}, \mathrm{S})$ of both sulfated sunflower and cotton seed oils were done to have a view about the percent ratio of the carbon, hydrogen and sulfer and the formation of the sulfated anionic surfactants.

Egypt. J. Chem. 53, No. 4 (2010) 
From the obtained results it could be also noticed that sulfated cotton seed oil had higher yields (71\%) compared with sunflower oil (61\%).

Preparation of anionic surfactants by sulfonation process

Preparation of anionic surfactants via reaction with $\mathrm{SO}_{3}$ gas. The advantage of this technique is the formation of a good yield product which is characterized by lower free oil and higher color compared with that obtained by the sulfatation process $^{(20)}$. In this method two types of sulfonating products are obtained via attacking the ester group or unsaturated double bond of fatty acids ${ }^{(2,21)}$.

The reaction can be illustrated in the following scheme :

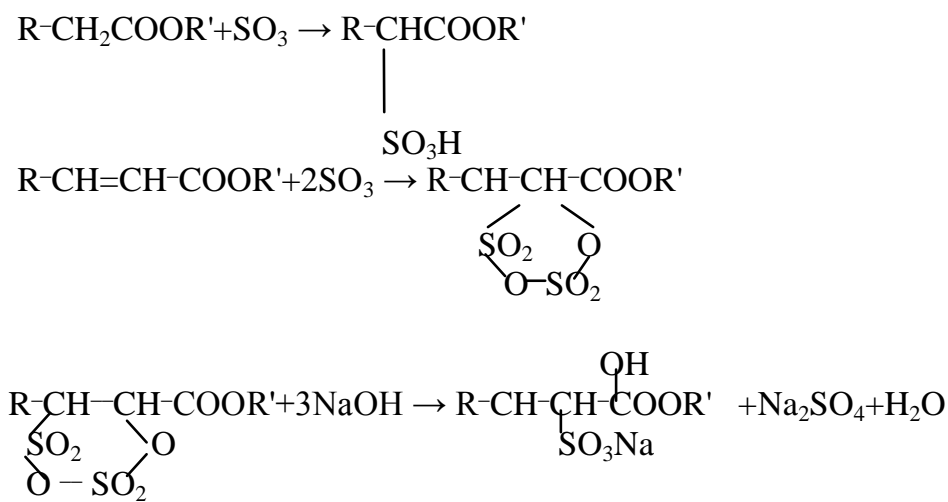

The yield and microanalyses of the prepared anionic surfactants are represented in Table 4.

TABLE 4. Yield and microanalysis of anionic surfactants by $\mathrm{SO}_{3}$.

\begin{tabular}{|l|c|c|c|c|c|c|c|}
\hline \multirow{3}{*}{ Sulfonated oil } & \multirow{2}{*}{$\begin{array}{c}\text { Yield } \\
(\%)\end{array}$} & \multicolumn{6}{|c|}{ Microanalysis } \\
\cline { 3 - 8 } & & Theo.* & Fd.** & Theo. & Fd. & Theo. & Fd. \\
\cline { 3 - 8 } & 70.0 & undefined & 16.74 & undefined & 2.87 & undefined & 12.37 \\
Sunflower & 71.0 & "'" & 17.44 & "'" & 3.00 & & 13.24 \\
Cotton seed & & & & & & & \\
\hline
\end{tabular}

${ }^{*}$ Theo $=$ Theoretical ${ }^{* *}$ Fd. $=$ Found 
The results given in Table 4 indicate that the yield of sulfonated sunflower and cotton seed oils are almost the same. On the other hand, the data of microanalysis of both sulfonated sunflower and cotton seed oils show acceptable values of $\% \mathrm{~S}$ which confirm the formation of sulfonated anionic surfactants. It noteworthy to mention that these results are in accordance with those reported by many investigators ${ }^{(23-25)}$.

\section{Evaluation and performance of the prepared anionic surfactants}

The anionic surfactants prepared by sulfatation or sulfonation were evaluated for, hydrophile-lipophile balance (HLB) , surface tension, interfacial tension, wetting power, foaming power, as well as, $\mathrm{PH}$ value.

The evaluation and performance characteristics of the prepared surfactants are shown in Table 5.

TABLE 5. Evaluation and performance of prepared anionic surfactants.

\begin{tabular}{|l|c|c|c|c|c|c|}
\hline Type of surfactant & HLP & $\begin{array}{c}\text { pH } \\
\text { value }\end{array}$ & $\begin{array}{c}\text { Surface } \\
\text { tension } \\
\text { dyne/cm }\end{array}$ & $\begin{array}{c}\text { Interfacial } \\
\text { tension } \\
\text { dyne/cm }\end{array}$ & $\begin{array}{c}\text { Wetting } \\
\text { power } \\
\text { time, sec. }\end{array}$ & $\begin{array}{c}\text { Foaming } \\
\text { power } \\
\text { vol.,ml. }\end{array}$ \\
\hline Sulfated sunflower & 9.5 & 7.4 & 38.0 & 10.0 & 39.0 & 135 \\
Sulfonated sunflower & 8.0 & 7.3 & 34.0 & 14.0 & 42.0 & 144 \\
Sulfated cotton seed & 13.0 & 7.3 & 33.0 & 11.0 & 30.0 & 129 \\
Sulfonated cotton seed & 12.0 & 7.1 & 31.0 & 13.5 & 32.0 & 132 \\
\hline
\end{tabular}

From the obtained results it can be noticed that the prepared surfactants varied in polarity over the entire HLB range (from 8.0 to 13.0) depending on their chemical composition. These HLB values can be attributed to the difference of fatty acid chain length, whereas high values can be obtained by using fatty acids with short chain length ${ }^{(3)}$. These results indicate that the surface tension of sulfonated sunflower oil and sulfated cotton seed oil have almost the same value 34.0 and 33.0 dyne/cm respectively. On the other hand, the interfacial tension values ranged from 10.0 to 14.0 dyne/sec.for both prepared surfactants. Prepared anionic surfactants via sulfonation process have better interfacial tension than those prepared by sulfatation process $(2,5,26)$.

The results also show that both wetting and foaming power of sulfonated oils are higher than those of sulfated oils. These higher values in foaming power of surfactant prepared by sulfonation process than those prepared by sulfatation process may be attributed to excess $\mathrm{SO}_{3}$ percentage in the prepared surfactants than sulfate group percentage $(1,13)$.

Biodegradability of the prepared anionic surfactants

Biodegradability is defined as the destruction of chemical compounds by the biological action of living organisms ${ }^{(27)}$. A simple example for the decomposition is as the following:

Egypt. J. Chem. 53, No. 4 (2010) 


$$
\mathrm{CH}_{2}-\mathrm{CH}_{2}+\mathrm{CH}_{2}-\mathrm{CH}_{2}+\mathrm{CH}_{2}-\mathrm{CH}_{2}+\mathrm{CH}_{2}-\mathrm{CH}_{2}+\mathrm{SO}_{3}
$$

Surfactant decomposition occurs every time by attacking 2 carbon atoms. In the last 10 years, biodegradability of surface active agent becomes under specific detergent legal requirements in Europe and Egypt as the following as given in Table 6.

TABLE 6. Biological legal requirements references.

\begin{tabular}{|c|c|c|}
\hline & Type of surfactant & \multicolumn{1}{c|}{ Legal requirement } \\
\hline 1 & Anionic surface active agent & $73 / 405$ S/EEC and 82/243/EEC \\
\hline 2 & Nonionic surface active agent & $73 / 405$ S/EEC and 82/242/EEC \\
\hline 3 & cationic surface active agent & $73 / 405$ S/EEC \\
\hline
\end{tabular}

Biodegradability of anionic surfactants prepared by sulfatation and sulfonation are presented in Table 7.

TABLE 7. Biodegradability of prepared anionic surfactants.

\begin{tabular}{|l|c|c|c|c|c|c|c|c|}
\hline \multirow{2}{*}{ Type of surfactants } & \multicolumn{7}{|c|}{ Days } \\
\cline { 2 - 10 } & 5 & 8 & 10 & 12 & 14 & 16 & 19 & 21 \\
\hline Sulfated sunflower & 57 & 68 & 74 & 80 & 87 & 94 & 97 & 99 \\
\hline Sulfonated sunflower & 53 & 66 & 72 & 79 & 86 & 92 & 99 & 99 \\
\hline Sulfated cotton seed & 49 & 61 & 68 & 75 & 83 & 90 & 96 & 99 \\
\hline Sulfonated cotton seed & 47 & 62 & 70 & 76 & 84 & 91 & 97 & 99 \\
\hline
\end{tabular}

From the obtained results it can be noticed that all prepared (sulfated or sulfonated) anionic surfactants have a degree of biodegradability which are higher than $80 \%$ after 14 days. These results are acceptable and meet the regulations reported by the Organization for Economic Corporation and Development (OECD) method for screening (OECD $11-6$ - 76) and easily meet 82 / 243 EEC directive requirements.

\section{References}

1. Fujimoto, T., "New Introduction to Surface Active Agents", Sanyo Chemical Industries Ltd, Japan, Part 3 , Chapter 3 , 187-218 (1985).

2. Groot, W.H., "Sulfonation Technology in the Detergent Industry", Kluwer Academic Publishers, Netherlands (1991).

3. Megahed, M.G., Sucrose polyesters from poultary fat as non-ionic emulsifiers. Grasas Aceites , 51. , 457-460, Spain (2000).

4. Karleskind, A., "Oils and Fats Manual", Lavoisier Publishing, Paris, France (1996). 
5. Fable, J., " Surfactants in Consumer Products" , Springer-Verlag, Heidelberg, Germany (1987).

6. A.O.C.S., "The Official and Tentative Methods of American Oil Chemist's Society", $3^{\text {rd }}$ ed. American Oil Chemist's Society (1995).

7. Mitruke, B.N., "Gas Chromatographic Applications in Micro-Biology and Medicine", John Wiley \& Sons Inc. New York (1984).

8. Marei, A. and Badawi, A.M., U.A.R. ; C.A., 13,187-197 (1970) .

9. Pore, J. and Chasseboeuf, C., "Les huiles sulfates, sulfones, leurs analogies, Lures Dissembalance", IV Congress International des Agents de Surface, Bruxelles, 7-12 Septembre (1976).

10. Griffin, W.C., "Emulsions": Encyclopedia of Chemical Technology, Vol. 8, 117-154, Interscience Publisher, New York, London, Sydney (1965).

11. Alexander, A.F. and Hayter, J.B, "Physical Methods of Chemistry". John Willy and Sons , New York. (1971).

12. Schigfner, R., Melliand Textiber, 41, 1275 (1960).

13. Ross, J. and Miles, G.D., Oil Soap , 18-99 (1941).

14. Jakobi G. and Lohr A., "Detergents and Textile Washing", VCH Verlagsgesellschaft, Weinheim, Germany (1987)

15.Verordnung and Reinigungsmitteln, Abbaubarken Abbaubarken anionischer und nichtioncher grenzflachenaktiver Stoffe in Wasch-und Reinigungsmmitteln vom 18.6. (1980)

16. Hassanein, M.M., "Changes in the Content and Composition of Lipids During Maturation of Soybean and Sunflower Seeds", M.Sc. Thesis, Faculty of Science, AinShams University, Egypt (1991).

17. Hassanein, M.M., "Studies on Biochemical Changes in Lipids of Some Maturing and Germination Oil Seeds", Ph.D. Thesis, Faculty of Science, Ain Shams University, Egypt (1996) .

18. Kajimoto, G. and Hotsuta, H., Changes in the contents and compositions of lipids, fatty acids, tocopherols and sterols in sunflower seed during maturation. J. Jap. Oil Chemist's Soc., 32 (3), 170-174 (1983).

19. Monga, P.K. Munshi, S.K. and Sukija, P.S., Lipid biosynthesis in the developing sunflower seeds. Plant Sci. Lett. 31(2-3), 311-21 (1983).

20. Roberts, D.W., Lawrence, J.G., Faiweather, I.A., Clemett, C.J. and Saul C.D., "Tenside Surfactant Detergent", 27, 82 (1990).

21. Schonk, R.M., Bakker, B.H. and Cerfonation, H., Recl. Trave. Chem. Pays-Bas, 111, 49 (1992).

22. Brit. Pat. 789, 199 (Aug. 6 ,1958).

Egypt. J. Chem. 53, No. 4 (2010) 
23. Green , H.A., "Olefin Sulfonates”, Part 2, Vol.7, Chapter 10, Mercel Dekker, New York, (1976).

24. Herron, S. J. Chem. Agri, 19, p. (Jul / Aug) (1993).

25. Hoyle, J., "The Chemistry of Functional Groups". John Wiley \& Sons, Ltd . Chichester, U.K. Chapter 10, p (1991).

26. Cullum, D.C. "Introduction to Surfactant Analysis". Blackie Academic and Professional, Glasgow G64, 2nz, Uk.5. Fable, J. (1987), "Surfactants In Consumer Products", Springer - Verlag Heidelberg, Germany (1992).

27. Swishev R. D., Arch. Environ. Health 17, 232 (1986).

(Received $2 / 12 / 2009$; accepted 30/8 2010)

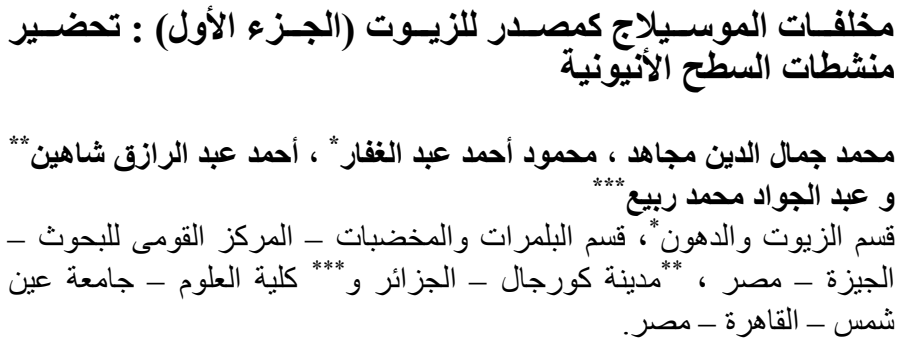

يعتبر الموسيلاج منتج ثانوي غني في نسبة الزيت. ولقد إهتمت الدراسة بتحديد

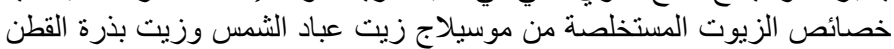

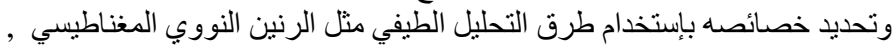

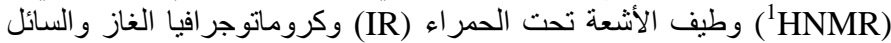

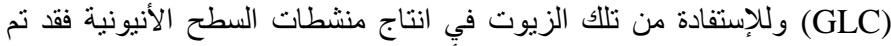

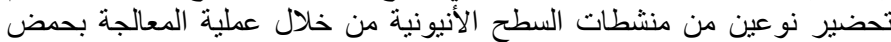

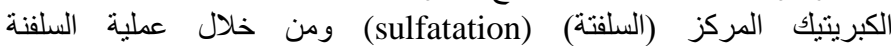
Sulfur trioxide بإستخدام غاز ثالث أكسيد الكبريت الجاف (sulfonation)

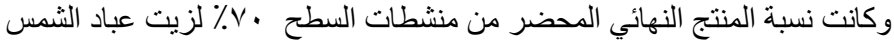

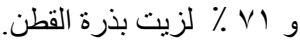

تم إجر اء تحليل لعناصر الكربون والهيدروجين والكبريت في المنتج النهائي

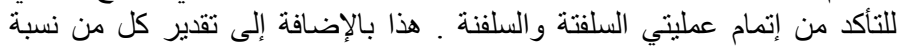

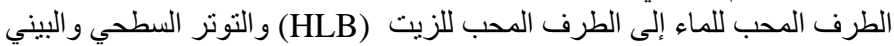

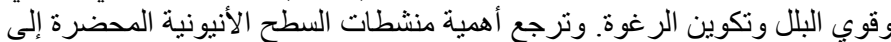

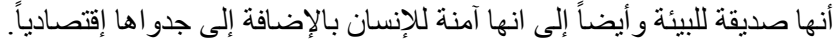

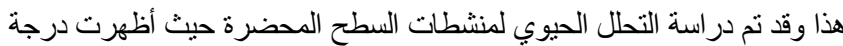

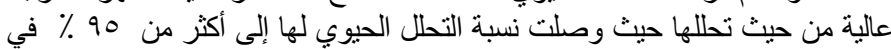
زمن أقل من ا ب يوم مما يؤكد مطابقتها للإنشتر اطات البيئية المحلية و العالمية. 